\title{
EFFECT OF MATING ON THE ONSET AND DURATION OF OVULATION IN THE SOW
}

\author{
J. P. SIGNORET, F. DU MESNIL dU BUISSON AND P. MAULÉON \\ I.N.R.A.-Station de Physiologie de la Reproduction, 37-Nouzilly, France
}

(Received 23rd May 1972, accepted 1st fune 1972)

Mating has been shown to have effects on ovulation in a number of species which ovulate spontaneously, such as rats (Aron, Asch \& Asch, 1961; Aron, Asch \& Ross, 1966; Zarrow \& Clark, 1968) and sheep (Parsons, Hunter \& Rayner, 1967; Van der Westhuysen, Van Niekerk \& Hunter, 1970). In the sow, the results obtained by Pitkjanen (1955) and Lebedev (1957) suggest that mating hastens ovulations and shortens the time during which ova are liberated. Direct inspection of the ovaries by coelioscopy (Locatelli, 1971) allows rapid and accurate determination of the time of ovulation and causes minimal trauma. By this technique, the earlier results have been confirmed in a preliminary experiment (Signoret, 1970).

The present experiment was designed to show by how many hours mating advances ovulation and shortens its total duration.

Fifty-nine Large White gilts were mated at the time of the second oestrus following withdrawal of methallibure (I.C.I.), which had been given for 21 days $(100 \mathrm{mg} /$ day in the feed) in order to control ovulation and to facilitate detection of the time of ovulation. The gilts were mated at the first sign of oestrus, and again $6 \mathrm{hr}$ later, by boars of known fertility. They were then randomly assigned to one of four experimental groups in which coelioscopy took place $30,35,40$ and $45 \mathrm{hr}$, respectively, after the onset of oestrus.

The time of ovulation in this group (A) was compared with that in a group of thirty-seven unmated gilts (B) given a single injection of PMSG $24 \mathrm{hr}$ after the last treatment with methallibure, and in a second control group $(\mathrm{C})$ of seventy-four unmated gilts on their second oestrus following withdrawal of methallibure. The findings in these last two groups have already been reported (du Mesnil du Buisson, Mauléon, Locatelli \& Mariana, 1970). Oestrus was detected by teaser boars put with the gilts for a few minutes every $6 \mathrm{hr}$ (Signoret, 1967).

The results are summarized in Table 1. By probit analysis (Finney, 1962), the median time between the beginning of oestrus and the start of ovulation was found to be $34.1 \mathrm{hr}$ in the mated animals (A) and $38.0 \mathrm{hr}$ in the controls (C). In the two groups, ovulations finished $35.0 \mathrm{hr}$ and $41.8 \mathrm{hr}$, respectively, after the start of oestrus.

Thus after two copulations, the median time for the onset of ovulation was $3.9 \mathrm{hr}$ earlier than in the unmated animals and the duration of ovulation was reduced by $2 \cdot 8 \mathrm{hr}$ (Text-fig. 1 ).

It has been suggested that the effects of stimuli associated with mating could be mediated by modifications in the patterns of discharge of pituitary gonado- 
TABLE 1

THE TIME OF OVULATION IN GILTS DURING OESTRUS

\begin{tabular}{|c|c|c|c|c|c|c|c|}
\hline \multirow{2}{*}{ Treatment } & \multirow{2}{*}{$\begin{array}{l}\text { Ovarian } \\
\text { response }\end{array}$} & \multicolumn{5}{|c|}{$\begin{array}{l}\text { Time interval from onset of oestrus } \\
\text { to coelioscopy }(h r)\end{array}$} & \multirow{2}{*}{ Probit lines } \\
\hline & & 30 & 35 & 40 & 45 & 50 & \\
\hline \multirow{3}{*}{$\begin{array}{l}\text { Mated } 0 \mathrm{hr} \\
\text { and } 6 \mathrm{hr} \\
\text { after onset of } \\
\text { oestrus } \\
\text { (Group A) }\end{array}$} & $\begin{array}{l}\text { Ovulation } \\
\text { completed } \\
\text { (1) }\end{array}$ & $4 / 14$ & $8 / 14$ & $9 / 14$ & $15 / 15$ & - & $\begin{aligned} y_{1}= & 0.83+0.12 x \\
& D E 50=35.03 \mathrm{hr}\end{aligned}$ \\
\hline & $\begin{array}{l}\text { Ovulation } \\
\text { in progress } \\
(2)\end{array}$ & 0 & 0 & $3 / 16$ & 0 & - & \\
\hline & $\begin{array}{l}\text { No } \\
\text { ovulation } \\
(3)\end{array}$ & $10 / 14$ & $6 / 14$ & $4 / 16$ & 0 & - & $\begin{aligned} y_{2}= & 10 \cdot 18-0.15 \times \\
& \operatorname{DE~} 50=34.06 \mathrm{hr}\end{aligned}$ \\
\hline \multirow[t]{3}{*}{$\begin{array}{l}\text { Unmated } \\
\text { (Group C) }\end{array}$} & $\begin{array}{l}\text { Ovulation } \\
\text { completed } \\
\text { (1) }\end{array}$ & $1 / 14$ & $4 / 15$ & $4 / 16$ & $9 / 15$ & $14 / 14$ & $\mathrm{y}_{1}=\frac{-0.72+0.14 \times}{\mathrm{DE} 50=41.77 \mathrm{hr}}$ \\
\hline & $\begin{array}{l}\text { Ovulation } \\
\text { in progress } \\
(2)\end{array}$ & 0 & $2 / 15$ & $5 / 16$ & $4 / 15$ & 0 & \\
\hline & $\begin{array}{c}\text { No } \\
\text { ovulation } \\
(3)\end{array}$ & $13 / 14$ & $9 / 15$ & $7 / 16$ & $2 / 15$ & 0 & $\begin{aligned} y_{2}^{\prime}= & 11.37-0.17 \times \\
& \operatorname{DE} 50=37.95 \mathrm{hr}\end{aligned}$ \\
\hline
\end{tabular}

(1) All large follicles ruptured (DE $50=$ mean time of onset of ovulation).

(2) Some large follicles not ruptured.

(3) No follicle ruptured (DE $50=$ mean time of end of ovulation).

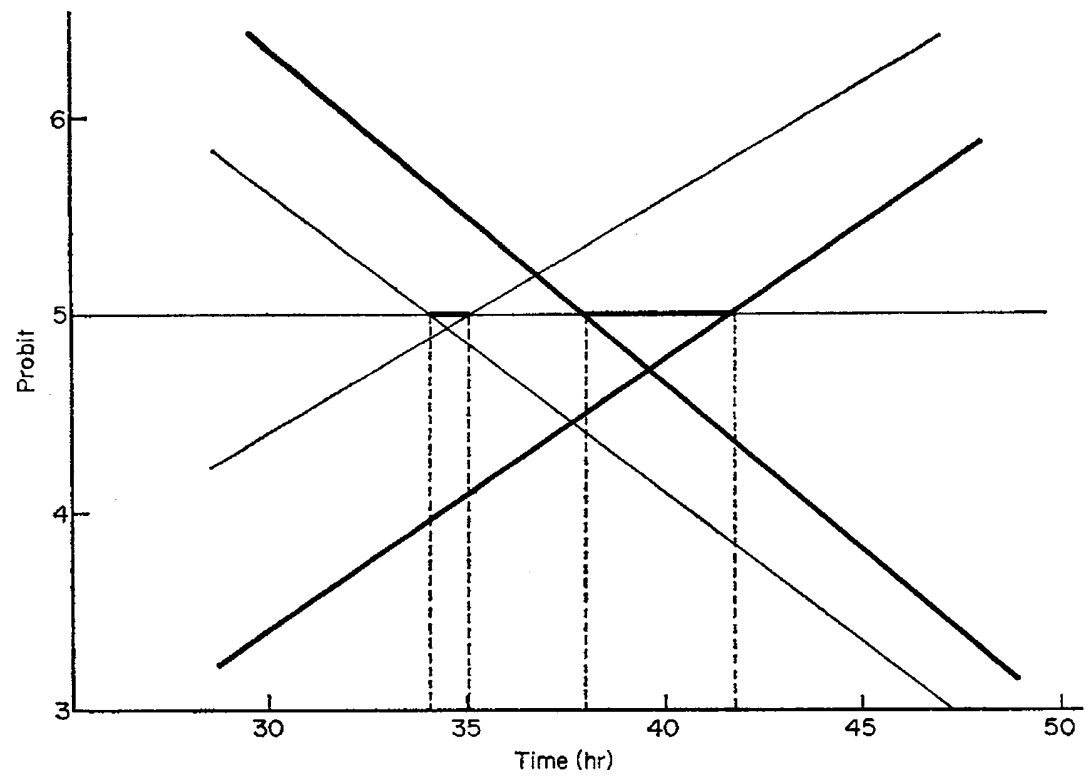

TEXT-Fig. 1. Percentage of sows ovulating (as probit) at different times after the onset of oestrus. 
trophins that take place within the first $8 \mathrm{hr}$ after the onset of oestrus (Niswender, Reichert \& Zimmerman, 1970). A single injection of PMSG also reduces the duration of ovulation (Group B) (du Mesnil du Buisson et al., 1970) (Table 2).

Our results differed from those of Zimmerman \& Naber (1971) who found that two copulations $12 \mathrm{hr}$ apart did not affect the time of onset or the duration of ovulation. It is possible that we have obtained different results because multiple matings may not affect ovulation unless they occur during the short

TABLE 2

EFFECT OF PMSG ON THE TIME OF OVULATION IN GILTS

\begin{tabular}{|c|c|c|c|c|c|c|c|}
\hline \multirow{2}{*}{ Treatment } & \multirow{2}{*}{$\begin{array}{l}\text { Ovarian } \\
\text { response }\end{array}$} & \multicolumn{5}{|c|}{$\begin{array}{l}\text { Time interval from onset of oestrus } \\
\text { to coelioscopy }(h r)\end{array}$} & \multirow{2}{*}{ Probit lines } \\
\hline & & 30 & 35 & 40 & 45 & 50 & \\
\hline \multirow{3}{*}{$\begin{array}{l}\text { PMSG ( } 750 \\
\text { i.u.) } 24 \mathrm{hr} \\
\text { after the last } \\
\text { treatment } \\
\text { with } \\
\text { methallibure } \\
\text { (Group B) }\end{array}$} & $\begin{array}{l}\text { Ovulation } \\
\text { completed } \\
\text { (1) }\end{array}$ & 0 & 0 & $1 / 8$ & $4 / 6$ & $4 / 4$ & $\begin{aligned} y_{1}= & 0 \cdot 29+0 \cdot 12 \times \\
& D E 50=43.57 \mathrm{hr}\end{aligned}$ \\
\hline & $\begin{array}{l}\text { Ovulation } \\
\text { in progress } \\
(2)\end{array}$ & $1 / 9$ & $2 / 10$ & $1 / 8$ & 0 & 0 & \\
\hline & $\begin{array}{c}\text { No } \\
\text { ovulation } \\
(3)\end{array}$ & $8 / 9$ & $8 / 10$ & $6 / 8$ & $2 / 6$ & 0 & $\begin{aligned} y_{2}^{\prime \prime}= & 42 \cdot 04-0.10 x \\
& D E 50=43.39 \mathrm{hr}\end{aligned}$ \\
\hline
\end{tabular}

(1) All large follicles ruptured (DE $50=$ mean time of onset of ovulation).

(2) Some large follicles not ruptured.

(3) No follicle ruptured (DE $50=$ mean time of end of ovulation).

time during which the rate of LH discharge is increasing at the beginning of oestrus (Niswender et al., 1970).

The authors are indebted to Dr A. G. Davies for his help in preparing the English translation of the manuscript and to Dr R. V. Short for critical reading of the manuscript.

The surgery was performed by A. Locatelli; his collaboration is gratefully acknowledged.

\section{REFERENCES}

Aron, Gl., Asch, G. \& Asch, L. (1961) Déclenchement de la ponte ovulaire et de la lutéinisation par la rapprochement sexuel chez les mammifères dits à ponte spontanée. Expériences chez la ratte. C.r. Séanc. Soc. Biol. 155, 2173.

Aron, Cl., Asch, G. \& Ross, J. (1966) Triggering of ovulation by coitus in the rat. Int. Rev. Cytol. 20, 139.

du Mesnil du Buisson, F., Mauléon, P., Locatelli, A. \& Mariana, J. G. (1970) Modification du moment et de l'étalement des avulations après maîtrise du cycle sexuel de la truie. Coll. Sté Nat. Fert. Steril.: Inhibition de l'ovulation, p. 225. Masson Publ. Paris.

Finney, D. J. (1962) Probit analysis, 2nd edn. Cambridge University Press.

Lebedev, M. M. (1957) Influences réflexes sur le déroulement de l'ovulation et de la fécondation chez la truie. Prob. Physiol. Anim. Domest. U.S.S.R., 249.

Locatelir, A. (1971) Technique coelioscopique pour l'examen des ovaries de la truie. Annls Biol. anim. Biochim. Biophys. 11, 495.

Parsons, S. D., Hunter, G. L. \& Rayner, A. A. (1967) Use of probit analysis in a study of the effect of the ram on time of ovulation in the ewe. 7 . Reprod. Fert. 14, 71. 
PItkjanen, I. G. (1955) Quelques lois de l'ovulation, de la fécondance et des premières phases de développement embryonnaire chez le porc. Bull. Acad. Sci., U.S.S.R., Ser. Biol. 3, 120.

Niswender, G. D., Reichert, L. E., JR \& Zimmerman, D. R. (1970) Radioimmunoassay of serum levels of luteinizing hormone throughout the oestrous cycle in pigs. Endocrinology, 87, 576.

Signoret, J. P. (1967) Durée du cycle et de l'oestrus chez le truie. Action du benzoate d'oestradiol chez la femelle ovariectomisée. Annls Biol. anim. Biochim. Biophys. 7, 407.

SignoRET, J. P. (1970) Swine behavior in reproduction. In: Symp. Proc. 70-0 Effect of disease and stress on reproductive efficiency in swine, p. 28. Ext. Serv. Univ. Nebraska Coll. Agric.

VAN der Westhuysen, J. M., VAn Niekerk, C. H. \& Hunter, G. L. (1970) Duration of oestrus and time of ovulation in sheep: effect of synchronisation, season and ram. Agroanimalia, 2, 131.

ZARROW, M. X. \& CLARK, J. H. (1968) Ovulation following vaginal stimulation in a spontaneous ovulator and its implications. F. Endocr. 40, 343.

Zimmerman, D. R. \& Naber, C. (1971) Influence of mating on ovulation time in the pig. F. Anim. Sci. 33, 273. 